\title{
Stable chlorine isotopes in saline springs from the Nangqen basin, Qinghai-Tibet Plateau: Brine genesis and evolution
}

\author{
Ji-Long Han ${ }^{1,2, *} \odot$, Syed-Asim Hussain ${ }^{1,2,3}$ and Feng-Qing Han ${ }^{1,2}$ \\ ${ }^{1}$ Key Laboratory of Comprehensive and Highly Efficient Utilization of Salt Lake Resources, Qinghai Institute of Salt \\ Lakes, Chinese Academy of Sciences, Xining 810 008, Qinghai Province, People's Republic of China. \\ ${ }^{2}$ Qinghai Provincial Key Laboratory of Geology and Environment of Salt Lakes, Qinghai Institute of Salt Lakes, \\ Chinese Academy of Sciences, Xining 810 008, Qinghai Province, People's Republic of China. \\ ${ }^{3}$ University of Chinese Academy of Sciences, Beijing 100 049, People's Republic of China. \\ *Corresponding author. e-mail: hjl@isl.ac.cn
}

MS received 16 April 2018; revised 9 May 2019; accepted 13 May 2019

Chlorine isotopes can be used to study the evolution of different fluids, sources and the causes of various related deposits. In this study, $\mathrm{Cl}$ concentrations and chlorine isotope $\left(\delta^{37} \mathrm{Cl}\right.$, IAEA ISL-354 $\mathrm{NaCl}$ standard) values were determined for brine samples from Nangqen basin, located on the southern boundary of the Qinghai-Tibet plateau to study the source and the processes of these saline springs. The results demonstrated that the saline springs are distributed around a fault or fault zone, with a high average salinity of $228.30 \mathrm{~g} / \mathrm{l}$ and flow rates ranging from 1.7 to $0.01 \mathrm{l} / \mathrm{s}$. $\mathrm{Na}^{+}$and $\mathrm{Cl}^{-}$are the predominant cations and anions, respectively, accounting for more than $90 \%$ of the total. The $\delta^{37} \mathrm{Cl}$ values range from $-1.55 \%$ o to $+0.97 \%$, and the $\mathrm{Cl} / \mathrm{Br}$ ratios are from 1739 to 175,260 . Coupled with the previous $\mathrm{H}$, $\mathrm{O}$ and $\mathrm{B}$ isotope compositions $\left(\delta \mathrm{D}\right.$, VSMOW2 standard, ranges from $-100.91 \%$ o to $-132.98 \%$, $\delta^{18} \mathrm{O}$, VSMOW2 standard, from $-12.88 \%$ to $-16.05 \%$ and $\delta^{11} \mathrm{~B}$, NIST 951 standard, from $+3.55 \%$ to $+29.59 \%$ ) , it can be interpreted that the saline springs are mainly the result of the dissolution of halite hosted in mudstone and volcanic country rocks.

Keywords. $\delta^{37} \mathrm{Cl}$; brine genesis; saline springs; Nangqen basin.

\section{Introduction}

Nangqen basin is located in the area spanning from $96^{\circ} 00^{\prime}-97^{\circ} 00^{\prime} \mathrm{E}$ and $32^{\circ} 00^{\prime}-32^{\circ} 40^{\prime} \mathrm{N}$ and was formed between the Late Eocene and Early Oligocene era (Deng et al. 2000). The terrain of the Nangqen basin is very steep, causing a series of northwest-south-east fault zones. Many saline springs are exposed adjacent to the fault zones, and they are characterised by high salinities (salinity is greater than $150 \mathrm{~g} / \mathrm{l}$ ) and large distribution areas $\left(10,000 \mathrm{~km}^{2}\right)$, which are most likely the result of Published online: 22 July 2019 the dissolution of the salt occurring underground (Han et al. 2018). The study of the brine geochemistry can allow the geochemical information of the underground salt layer to be determined and help predict the salt formation and mineralisation. However, little work has been done to investigate the formation and geochemical processes of saline springs in this area. Therefore, stable chlorine isotopes are used here to indicate the source and evolution of brine.

Chlorine is an abundant element in the oceans, salt lakes and related geological systems, and it 
is brought into the salt lake through various channels, providing important information regarding the evolution of brine. Chlorine is the abundant anion in many geofluids and one of the chief volatile constituents on Earth (Bureau et al. 2000; Bonifacie et al. 2008). ${ }^{35} \mathrm{Cl}$ and ${ }^{37} \mathrm{Cl}$ are two naturally occurring stable isotopes, with a relative mass difference of $5.7 \%$, and the natural range in the variation in $\delta^{37} \mathrm{Cl}$ is approximately $7 \%$ ( $\mathrm{Liu}$ et al. 1998; Xu et al. 2008; Barnes and Sharp 2017). Based on the mass fractionation of the two stable chlorine isotopes $\left({ }^{35} \mathrm{Cl}=75.53 \%\right.$ and $\left.{ }^{37} \mathrm{Cl}=24.47 \%\right)$ in natural environments, the element can be used as a tracer in many geochemical processes (Luo et al. 2012). Due to the development of high-precision chlorine isotope determination methods, the research on chlorine isotope fractionation in nature has achieved many results and promoted an in-depth study of chlorine isotope tracing in geochemistry (Magenheim et al. 1994; Xiao et al. 1994; Eggenkamp and Schuiling 1995; Tan et al. 2005). Chlorine isotopes are currently used as tracers to allow the tracing of the sources and the evolution of seawater, salt lake brines, groundwater, surface river water, evaporative rocks and hydrothermal fluids (Eastoe and Guilbert 1992; Eggenkamp et al. 1995; Banks et al. 2000; Gleeson and Smith 2009; Nahnybida et al. 2009; Richard et al. 2011). $\delta^{37} \mathrm{Cl}$ values have been consistently proximate to the marine water values $(0 \%)$, and range from $3.0 \%$ to $7.2 \%$ in mantle and crust (Sharp et al. 2007). On the other hand, large surface reservoirs (evaporites, brines and the oceans) have exhibited mean $\delta^{37} \mathrm{Cl}$ values of $0.05 \%$ to $\pm 0.5 \%$ o (Eggenkamp et al. 1995; Godon et al. 2004; Eastoe et al. 2007). Brines from salt lakes may range from $-2.05 \%$ to $+1.01 \%$ or slightly higher (Liu et al. 1997; Luo et al. 2012).

During the formation and evolution of brine, the chlorine isotope composition can exhibit corresponding differences due to factors such as the source of the supplemental water and evaporation (Liu and Xiao 1996). Vengosh's study shows that ${ }^{37} \mathrm{Cl}$ tends to concentrate in precipitated salt, compared to the source fluid, in the process of brine evaporation and halite deposition (Vengosh et al. 1989; Eggenkamp et al. 1995; Xiao et al. 2000). This fractionation of chlorine isotopes observed in the evaporation process of brines is also seen in the study of the Qaidam basin and the Michigan basin (Kaufmann et al. 1993; Luo et al. 2012, 2015). A large number of evaporation experiments have shown that ${ }^{37} \mathrm{Cl}$ is enriched in salt deposits. As the evaporation process continues, the amount of salt minerals gradually decreases, and the amount of ${ }^{37} \mathrm{Cl}$ in the brine is continuously depleted. In addition, the $\delta^{37} \mathrm{Cl}$ value gradually decreases in solid minerals precipitated at various stages of brine evaporation (Vengosh et al. 1989; Liu and Xiao 1996; Rodríguez et al. 1997).

In this study, $\mathrm{Cl}$ concentrations and $\delta^{37} \mathrm{Cl}$ values were determined for all brine samples from the Nangqen basin. The aims were to delineate the geochemical origins of saline springs of the Nangqen basin and study the evolution and sources of the saline springs.

\section{Geology and tectonic setting}

The Nangqen basin is located on the eastern Qinghai-Tibetan plateau, on the north-eastern edge of the Qiangtang-Changdu area between the Jinshajiang suture and the Nujiange suture. It is a Tertiary inland basin, formed by the collision of the Eurasian and Indian plates. The long-term uplift and denudation of the Mesozoic basement has also contributed to the formation of the basin (Deng et al. 2000; Qi et al. 2017). As shown in figure 1, the exposed surface layers are relatively limited to the Mesoproterozoic, Carboniferous, Permian, Triassic, Palaeogene, Neogene and Quaternary. In addition, a small area of Cretaceous volcanic rocks and Palaeogene volcanic rocks are also exposed in the north-eastern area. The boundary of the basin is controlled by the faults, and their directions are north-west and south-east. The western boundary is eroded, and it is surrounded by the complex deformation of the Carboniferous-Permian Marine carbonate rocks, while the source area of the basin sediments consists of carbonate rocks and (purplered) clastic rocks of the Triassic-Jurassic age and show parallel or angular unconformity. The formation time of the basin is from the Late Eocene to the Early Oligocene, the folds are widespread and the red continental clastic rock formation contains evaporates and is accompanied by massive highpotassium rocks (mainly volcanic rocks). The volcanic rocks in the basin occur as narrow and strip-shaped or round, and the small-scale outcrops are only a few hundred metres long and tens of metres wide. Volcanic activity is characterised by early eruption and a late overflow eruption cycle. Early volcanoclastic rocks were mainly distributed in the eastern part of the basin. Late volcanic activity mainly consists of coarse surface rocks and 


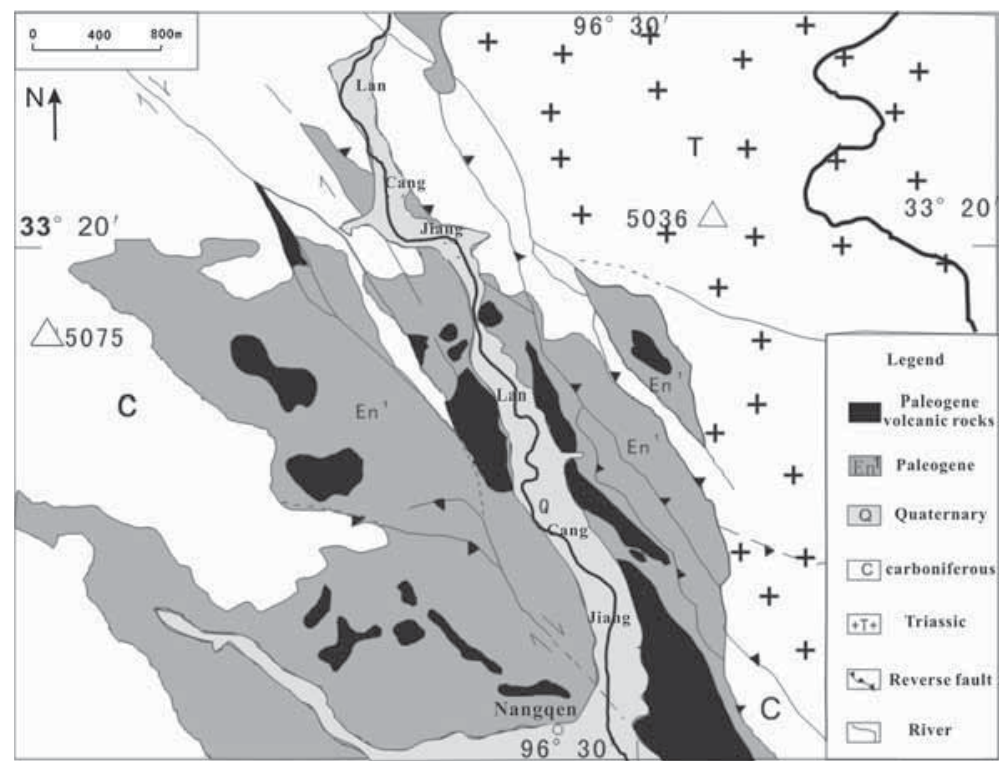

Figure 1. Geological sketch of Nangqen basin. (Modified after Deng et al. 2000).

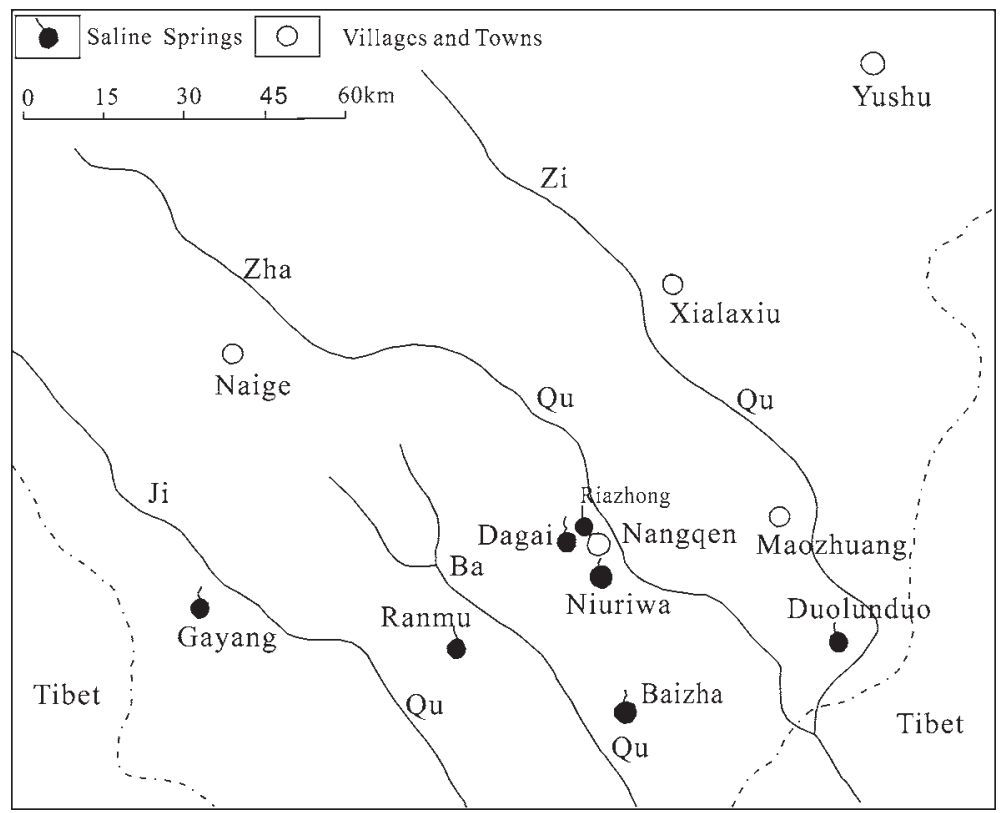

Figure 2. Distribution of the saline springs in the Nangqen basin.

shallow intrusive rocks (Yang 1988; Jiang et al. 2006). Many rivers flow through the area, i.e., the Lancang river (Zhaqu), Ziqu, Jiqu and Baqu. Until now, seven saline springs have been located and utilised. The saline springs exposed are mainly located in the volcanic rocks of the Eocene series and in conglomerate and carbonate sandstones of the Miocene series (figure 2).

In the study area, a series of fractures, which are very important for the formation and development of the basin, can be found to the north-west and southeast, and the saline springs are exposed in the fault zones. The imbalanced development and multiperiodic activity of these fractures are concluded to be conducive to the formation of a salt basin tectonic environment (Brian et al. 2000; Spurlin et al. 2015).

\section{Samples and analytical methods}

\subsection{Sample collection}

Through data collection and field investigation, we analysed the samples of seven saline springs in the Nangqen basin. All the samples were collected in 
Table 1. Sampling sites.

\begin{tabular}{|c|c|c|c|}
\hline Saline spring & Location & Rock type & Age \\
\hline Dagai & $\begin{array}{l}\mathrm{N} 32^{\circ} 12^{\prime} 15.1^{\prime \prime} \\
\mathrm{E} 96^{\circ} 26^{\prime} 09.4^{\prime \prime}\end{array}$ & Sandstone + mudstone & Palaeogene \\
\hline Riazhong & $\begin{array}{l}\mathrm{N} 32^{\circ} 15^{\prime} 58.8^{\prime \prime} \\
\mathrm{E} 96^{\circ} 27^{\prime} 00.7^{\prime \prime}\end{array}$ & Sandstone, gypsum + mudstone & \\
\hline Niuriwa & $\begin{array}{l}\mathrm{N} 32^{\circ} 08^{\prime} 38.7^{\prime \prime} \\
\mathrm{E} 96^{\circ} 28^{\prime} 28.2^{\prime \prime}\end{array}$ & Sandstone, gypsum + mudstone & \\
\hline Duolunduo & $\begin{array}{l}\mathrm{N} 32^{\circ} 04^{\prime} 48.5^{\prime \prime} \\
\mathrm{E} 96^{\circ} 56^{\prime} 14.7^{\prime \prime}\end{array}$ & Sandstone, volcanic rock + mudstone & \\
\hline Baizha & $\begin{array}{l}\mathrm{N} 31^{\circ} 56^{\prime} 02.6^{\prime \prime} \\
\mathrm{E} 96^{\circ} 36^{\prime} 07.9^{\prime \prime}\end{array}$ & Sandstone + mudstone & \\
\hline Ranmu & $\begin{array}{l}\mathrm{N} 32^{\circ} 26^{\prime} 43.1^{\prime \prime} \\
\mathrm{E} 95^{\circ} 50^{\prime} 51.9^{\prime \prime}\end{array}$ & Clay & \\
\hline Gayang & $\begin{array}{l}\mathrm{N} 32^{\circ} 03^{\prime} 47.9^{\prime \prime} \\
\mathrm{E} 95^{\circ} 39^{\prime} 41.1^{\prime \prime}\end{array}$ & Sandstone + mudstone & \\
\hline
\end{tabular}

December 2016, and the sampling locations are shown in table 1.

\subsection{Analytical methods}

\subsubsection{Chlorine isotope}

Chlorine isotope sample processing and testing process: As the $\mathrm{SO}_{4}{ }^{2-}$ and $\mathrm{NO}_{3}{ }^{-}$ions interfere significantly with chlorine isotope determination, we sequentially passed the aqueous solution through a Ba-type resin to remove the $\mathrm{SO}_{4}{ }^{2-}$ ions and an Ag-type resin to remove the $\mathrm{NO}_{3}{ }^{-}$ions, followed by an $\mathrm{H}$-type resin to remove all the cations and to convert the $\mathrm{Cl}^{-}$ions to $\mathrm{HCl}$. Finally, the solution was passed through a Cs-type resin to form $\mathrm{Cs}_{2} \mathrm{Cl}^{+}$. We coated the formed $\mathrm{Cs}_{2} \mathrm{Cl}^{+}$with a mass spectrometer metal tantalum tape. First, we vacuumed the tantalum tape used $(1.5 \mathrm{~cm} \times 0.098 \mathrm{~cm} \times 0.0025 \mathrm{~cm})$ at $3 \mathrm{~A}$ for $1 \mathrm{~h}$. Then, at the time of coating, $2.5 \mu \mathrm{l}$ of graphite suspension was applied to the tape surface, followed by drying under a 1.2-A current and steaming to near dry under a 1.2-A current, and then, the processed sample was added.

Mass spectrometry: We used a Thermo Fisher Triton thermal ionisation mass spectrometer (TIMS), with the main features as follows: a $90^{\circ}$ fan-shaped magnetic analyser with an effective radius of $81 \mathrm{~cm}$. When the acceleration voltage is $10 \mathrm{kV}$, the mass range is $3-320 \mathrm{amu}$, which provides the most precise and accurate isotopic ratio for both positive and negative ions; resolution: $\geq 450$ ( $10 \%$ peak and valley definition); sensitivity: $\geq 3$ ion $/ 100 \mu \mathrm{mol}$ or $1 / 500$; and abundance sensitivity: no filter $\leq 2 \mathrm{ppm}$, filter $\leq 10 \mathrm{ppb}$. The machine is a multi-collector TIMS which includes a central cup and eight independently movable Faraday cups that enable the determination of 303 $\left(\mathrm{Cs}_{2}^{37} \mathrm{Cl}^{+}\right) / 301\left(\mathrm{Cs}_{2}^{35} \mathrm{Cl}^{+}\right)$ions in static doubleaccepting chlorine isotopes.

Determination of $\mathrm{Cl}$ isotopic composition: We determined the chlorine isotopic composition using positive thermal ionisation mass spectrometry and graphite-based $\mathrm{Cs}_{2} \mathrm{Cl}^{+}$ions (Xiao et al. 1998). After loading the sample into the mass spectrometer, we vacuumed the ion source to $2-3 \times 10^{-7} \mathrm{Mbar}$ and started the measurement. During analysis, we used the static double receiver method to determine the mode of detection and obtained the $\mathrm{R}_{303 / 301}$ value. In this experiment, the ${ }^{37} \mathrm{Cl} /{ }^{35} \mathrm{Cl}$ ratio was calculated based on $\mathrm{Cs}_{2} \mathrm{Cl}^{+}$, and the sample $\delta^{37} \mathrm{Cl}$ value was calculated as follows:

$$
\begin{aligned}
\delta^{37} \mathrm{Cl}(\% \mathrm{oo}) \\
=\left[\left({ }^{37} \mathrm{Cl} /{ }^{35} \mathrm{Cl}\right)_{\text {sample }} /\left({ }^{37} \mathrm{Cl} /{ }^{35} \mathrm{Cl}\right)_{\text {standard }}-1\right] \\
\quad \times 1000, \text { Error } \leq 0.09 \%,
\end{aligned}
$$

IAEA ISL-354 NaCl standard

$$
=0.319028 \pm 0.000058(n=12) .
$$

\subsection{2 $\mathrm{H}-\mathrm{O}$ and $\mathrm{B}$ isotopes}

For $\delta \mathrm{D}$ and $\delta^{18} \mathrm{O}$ isotopes, MAT253 (Thermo Fisher Scientific, USA) and a Flash HT-IRMS analysis system were used.

VSMOW2 was used as the $\mathrm{H}_{2} \mathrm{O}$ standard with $\delta \mathrm{D}_{\text {VSMOW }} / \%$ o $=0 \pm 0.3$ and $\quad \delta^{18} \mathrm{O}_{\text {VSMOW }} / \%$ o $=$ $0 \pm 0.02$. 
For $\delta^{11} \mathrm{~B}$ isotopes, a thermal ionisation mass spectrometer (Thermo Fisher Finnigan, Germany) were used. The $\mathrm{B}$ isotopic composition can be expressed as follows:

$$
\begin{aligned}
& \delta^{11} B(\%)= {\left[\left({ }^{11} \mathrm{~B} /{ }^{10} \mathrm{~B}\right)_{\text {sample }} /\left({ }^{11} \mathrm{~B} /{ }^{10} \mathrm{~B}\right)_{\text {standard }}-1\right] } \\
& \times 1000, \\
&\left({ }^{11} \mathrm{~B} /{ }^{10} \mathrm{~B}\right)_{\text {standard }} \text { NIST } 951 \\
&= 4.05262 \pm 0.00077(2 \sigma=0.02 \%, n=9) .
\end{aligned}
$$

Test details were obtained from a previous work (Han et al. 2018).

\section{Results}

The results of the hydrochemical analysis and $\delta \mathrm{D}$, $\delta^{18} \mathrm{O}, \quad \delta^{11} \mathrm{~B}$ values of all samples are shown in tables 2 and 3 (Han et al. 2018). The flow rates of the seven salt springs in this area are quite different, with the largest being $1.7 \mathrm{l} / \mathrm{s}$ and the smallest being $0.01 \mathrm{l} / \mathrm{s}$. Moreover, the saline springs are distributed around the faults or fault zones. The salinity of the saline springs is very high, with an average value of $228.30 \mathrm{~g} / \mathrm{l} \mathrm{Na}^{+}$and $\mathrm{Cl}^{-}$are the predominant cations and anions, respectively, accounting for more than $90 \%$ of the total. The chlorine isotope values range from $-1.55 \%$ to $+0.97 \%$, which is a large variation and indicate that several factors are responsible. The $\mathrm{Ca}^{2+}$ and $\mathrm{Mg}^{2+}$ content values are both below $3 \mathrm{~g} / \mathrm{l}$, and the $\mathrm{K}^{+}$content is relatively lower, with a range from 0.08 to $0.36 \mathrm{~g} / 1 . \mathrm{SO}_{4}{ }^{2-}$ is second only to $\mathrm{Cl}^{-}$in the anion content of the saline springs, with a wide range of variation from 2.97 to $29.41 \mathrm{~g} / \mathrm{l}$. The content of B in Duolunduo is relatively high, reaching a maximum of $200.56 \mathrm{mg} / \mathrm{l}$ and a minimum of $1.00 \mathrm{mg} / \mathrm{l}$ in Ranmu. The content of $\mathrm{Li}^{+}$in
Table 3. $\delta D, \delta^{18} O$ and $\delta^{11} B$ analysis of the saline springs, Nangqen basin.

\begin{tabular}{lccccc}
\hline Samples & $\begin{array}{c}\delta^{11} \mathrm{~B} \\
(\%)\end{array}$ & $\delta \mathrm{D}(\%)$ & $\begin{array}{c}\delta^{18} \mathrm{O} \\
(\% \mathrm{o})\end{array}$ & $\begin{array}{c}\mathrm{Cl} / \mathrm{Br} \\
(\mathrm{mol} / \mathrm{mol})\end{array}$ & \multicolumn{1}{c}{$\begin{array}{c}\delta^{37} \mathrm{Cl} \\
(\%)\end{array}$} \\
\hline Dagai & $4.85^{*}$ & $-127.39^{*}$ & $-14.52^{*}$ & 60,769 & \multicolumn{1}{c}{-0.6} \\
Riazhong & $12.7^{*}$ & $-128.28^{*}$ & $-14.68^{*}$ & 33,412 & -1.07 \\
Niuriwa & $18.01^{*}$ & $-124.14^{*}$ & $-14.38^{*}$ & 91,252 & -0.03 \\
Duolunduo & $3.55^{*}$ & $-100.91^{*}$ & $-12.88^{*}$ & 1739 & -0.21 \\
Baizha & $12.96^{*}$ & $-132.98^{*}$ & $-16.00^{*}$ & 16,815 & -1.18 \\
Ranmu & $29.59^{*}$ & $-128.36^{*}$ & $-16.05^{*}$ & 175,620 & -0.87 \\
Gayang & $18.27^{*}$ & $-129.57^{*}$ & $-15.93^{*}$ & 93,823 & 0.04 \\
\hline
\end{tabular}

*Cited from preliminary results (Han et al. 2018).

Riazhong is $27.17 \mathrm{mg} / \mathrm{l}$ and below $10.00 \mathrm{mg} / \mathrm{l}$ in the other saline springs, with the lowest value being $1.03 \mathrm{mg} / \mathrm{l}$ in the Ranmu saline springs.

\section{Discussion}

\section{$5.1 \mathrm{H}, \mathrm{O}$ and $B$ isotopes}

Metrics such as hydrogen-oxygen isotopes $(\mathrm{H}-\mathrm{O})$ and $B$ isotopes of the saline springs in the Nangqen basin have been previously studied by our research group, as shown in figure 3 . For the $\mathrm{H}$ and $\mathrm{O}$ isotopes, the data of all seven samples were near the global water line value, which indicated that the sources of the saline springs are atmospheric precipitation and infiltration. For $\delta^{11} \mathrm{~B}$, the $\delta^{11} \mathrm{~B}-\mathrm{B}$ relationships were analysed and the results showed that the leaching from the surrounding rocks (marine carbonate rocks and volcanic rocks) are the main sources of the B isotopes in the saline springs. It is speculated that the saline springs in the Nangqen basin were leached from the underground salt layer during atmospheric precipitation

\begin{tabular}{|c|c|c|c|c|c|c|c|c|c|c|c|}
\hline \multirow[b]{2}{*}{ Samples } & \multirow[b]{2}{*}{$\mathrm{pH}$} & \multirow[b]{2}{*}{$\begin{array}{l}\text { TDS } \\
(\mathrm{g} / \mathrm{l})\end{array}$} & \multicolumn{9}{|c|}{ Concentrations of major ions } \\
\hline & & & $\begin{array}{l}\mathrm{Na}^{+} \\
(\mathrm{g} / \mathrm{l})\end{array}$ & $\begin{array}{l}\mathrm{Ca}^{2+} \\
(\mathrm{g} / \mathrm{l})\end{array}$ & $\begin{array}{c}\mathrm{K}^{+} \\
(\mathrm{g} / \mathrm{l})\end{array}$ & $\begin{array}{c}\mathrm{Mg}^{2+} \\
(\mathrm{g} / \mathrm{l})\end{array}$ & $\begin{array}{c}\mathrm{Li}^{+} \\
\left(10^{-3} \mathrm{~g} / \mathrm{l}\right)\end{array}$ & $\begin{array}{c}\mathrm{B} \\
\left(10^{-3} \mathrm{~g} / \mathrm{l}\right)\end{array}$ & $\begin{array}{l}\mathrm{Cl}^{-} \\
(\mathrm{g} / \mathrm{l})\end{array}$ & $\begin{array}{c}\mathrm{SO}_{4}^{2-} \\
(\mathrm{g} / \mathrm{l}) \\
\end{array}$ & $\begin{array}{c}\mathrm{Br}^{-} \\
\left(10^{-3} \mathrm{~g} / \mathrm{l}\right)\end{array}$ \\
\hline Dagai & 7.52 & 165.75 & 62.07 & 1.13 & 0.08 & 0.21 & 1.84 & 3.56 & 96.12 & 5.38 & 3.09 \\
\hline Riazhong & 7.02 & 316.58 & 117.29 & 1.01 & 0.31 & 1.99 & 20.93 & 12.19 & 180.96 & 13.32 & 6.26 \\
\hline Niuriwa & 7.18 & 150.89 & 57.11 & 1.13 & 0.19 & 0.29 & 3.91 & 2.17 & 87.98 & 2.98 & 3.98 \\
\hline Duolunduo & 7.75 & 292.75 & 107.02 & 0.37 & 0.11 & 0.21 & 9.68 & 200.56 & 154.97 & 29.10 & 19.13 \\
\hline Baizha & 7.04 & 269.48 & 103.77 & 1.23 & 0.07 & 0.14 & 4.88 & 21.38 & 159.73 & 4.45 & 4.70 \\
\hline Ranmu & 7.14 & 229.26 & 86.03 & 1.19 & 0.29 & 0.41 & 0.75 & 1.74 & 135.77 & 4.49 & 20.30 \\
\hline Gayang & 7.22 & 150.28 & 55.93 & 1.70 & 0.09 & 0.35 & 2.24 & 2.07 & 86.29 & 5.52 & 5.25 \\
\hline
\end{tabular}
or groundwater upwelling and then formed on the exposed surface (Han et al. 2018).

Table 2. Geochemical analysis of the saline springs, Nangqen basin, (cited from preliminary results, Han et al. 2018). 

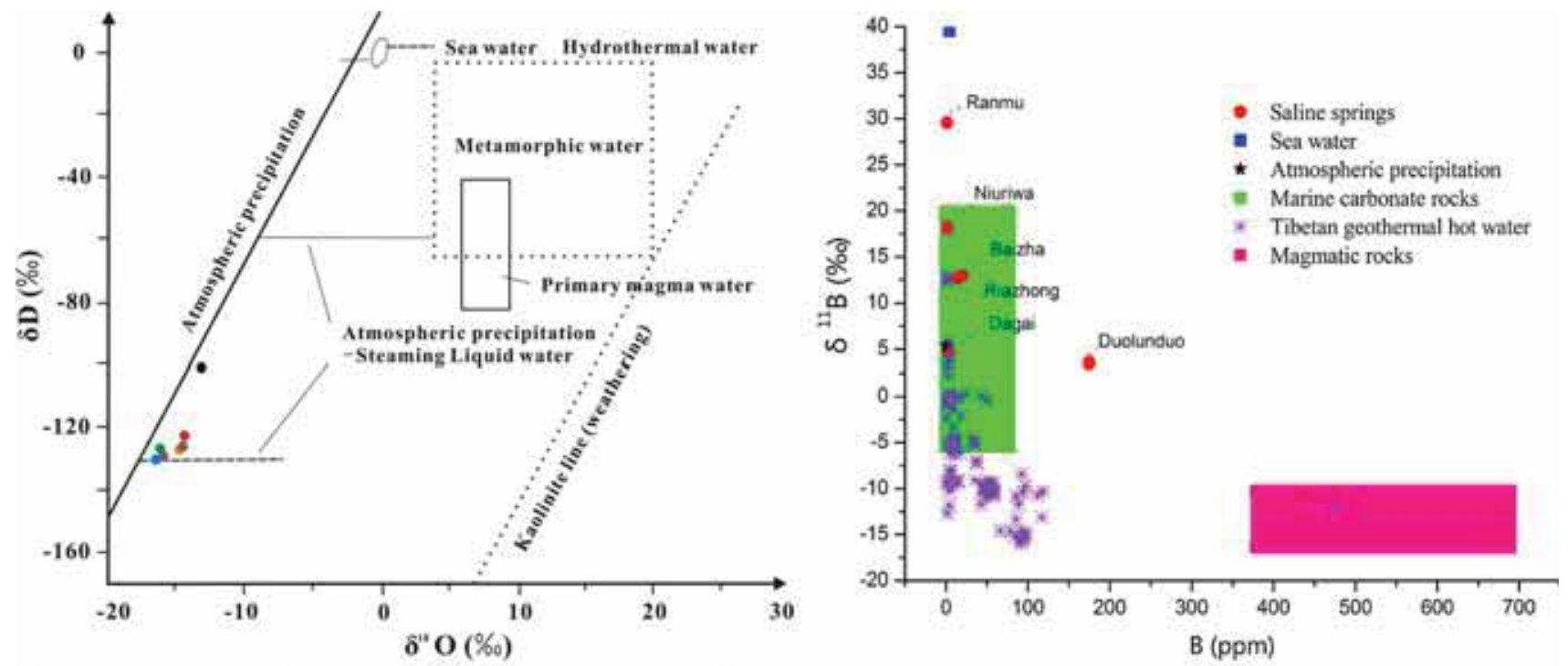

- Niuriwa $\bullet$ Riazhong $\bullet$ Duolunduo $\bullet$ Dagai $\bullet$ Baizha $\bullet$ Ranmu $\bullet$ Gayang

Figure 3. Isotope analysis of H, O and B (cited from Han et al. 2018). The green and pink shaded areas are the regions with boron geochemical characteristics of crustal marine carbonate rocks and magmatic rocks, respectively (Hemming and Hanson 1992). Tibetan geothermal hot water data are from Lv et al. (2014).

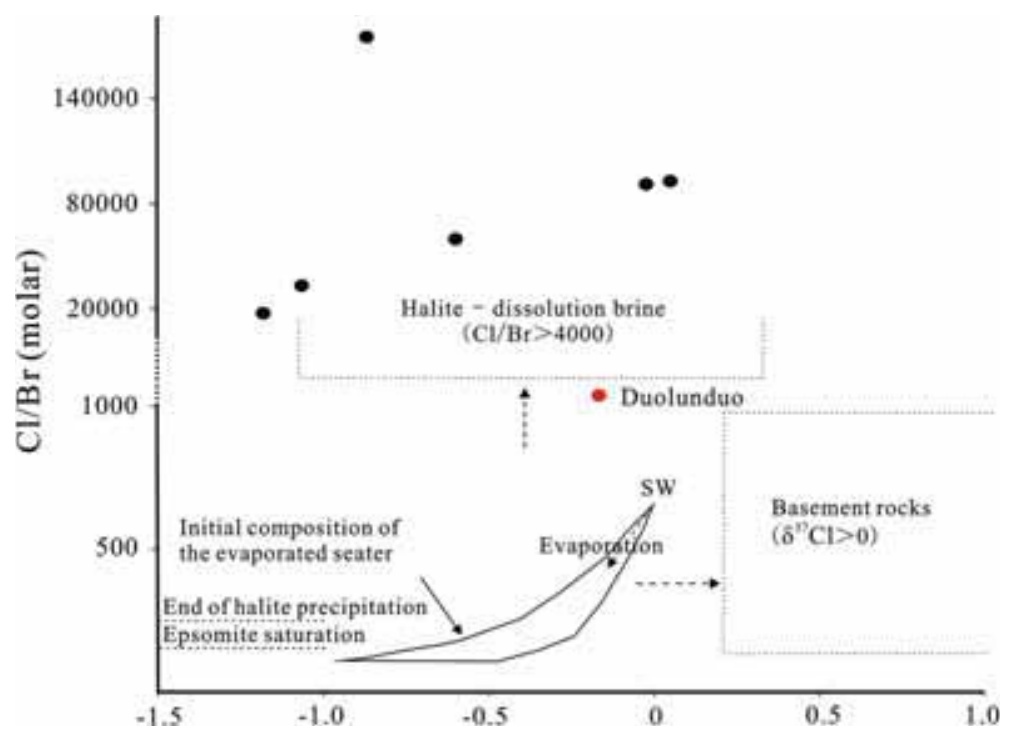

Figure 4. Relationship between the $\mathrm{Cl} / \mathrm{Br}$ molar ratios and $\delta^{37} \mathrm{Cl}$.

\subsection{Cl isotope tracer}

The $\mathrm{Cl}$ isotope analysis of these saline springs carried out in the present study further elucidates their sources and evolution (figure 4).

Several workers have analysed the relationship between the chlorine isotopes of various geological settings and the molar ratios of chlorine and bromine (Cl/Br) (Fontes and Matray 1993; Eggenkamp et al. 1995; Eastoe et al. 1999). According to the study of Banks et al. (2000), the dissolution-recrystallisation process of the halite does not cause a change in the $\mathrm{Cl} / \mathrm{Br}$ ratio of the brine, and the $\delta^{37} \mathrm{Cl}$ value is not affected (Banks et al. 2000). As a result, the value of $\delta^{37} \mathrm{Cl}$ in brine can reflect the dissolved halite characteristics. Bodnar's study showed that the dissolved chloride ion concentration of the halite is up to $\sim 170,000 \mathrm{ppm}$ at a temperature of $100^{\circ} \mathrm{C}$ and is $4000 \mathrm{ppm}$ at a temperature of $25^{\circ} \mathrm{C}$. Therefore, the halite dissolution characteristic value is 4000 (Bodnar 1994). 
By comparison, the $\mathrm{Cl} / \mathrm{Br}$ ratio of the brine in the Nangqen basin ranges from 1739 to 175,260. Excluding the Duolunduo saline spring value of 1739 , the $\mathrm{Cl} / \mathrm{Br}$ ratio in the other salt springs is much higher than the halite characteristic value of 4000 , which is within the halite dissolution characteristic value range (Chi and Savard 1997; Banks et al. 2000; Grandia 2003). However, the chlorine isotope values of some brines obviously exceed the range of halite eigenvalues, with a range from $-1.55 \%$ o to $+0.97 \%$, and this range of variation is far greater than the variation of $\mathrm{Cl}$ isotopes in seawater evaporation stages. This result also shows that the brines are non-marine sources. The brine isotope values show a greater range of variation due to the presence of multiple water bodies in the brines of continental origins (Risacher et al. 2003). The $\mathrm{Cl} / \mathrm{Br}$ ratios from a river or groundwater are comparable to those from seawater, but if mixed with brine before evaporation, the initial $\mathrm{Cl} / \mathrm{Br}$ of the evaporating solution will be very different from that of the seawater. The study by Liu et al. (1997) shows that the chlorine isotope in salt lake brines has a wide range of variation from $-2.05 \%$ o to $+1.01 \%$. Therefore, due to the high variation characteristics of chlorine isotopes, it is not sufficient to justify the source of the brine or marine origin of the brine based on the characteristic values of the chlorine isotopes. However, the common characteristics of the $\mathrm{Cl} / \mathrm{Br}$ ratios and the chlorine isotope characteristics indicate that the brine in this area belongs to a continental source. In addition, the Nangqen basin is in the collision zone of Eurasia and formed in the Mesozoic-Cenozoic era. This period is an era of very dry and hot climate in the history of the Earth, which is conducive to the formation of salt minerals. The underground strata of the basin are rich in salt (halite) and formed in the Cenozoic Eocene-Oligocene period (Horton et al. 2000; Du et al. 2011). The evidence from the chlorine isotope shows that the saline springs are mainly formed by the leaching of the underground halite layer, and consist of leached brine, which provides more forceful evidence for the formation and evolution of saline springs in the area.

\subsection{Water-rock processes}

During the process of halite leaching, the initial chlorine content of the brine is the same as that of the halite, but the $\mathrm{Cl} / \mathrm{Br}$ ratio and chlorine isotope characteristic values of the brine will be affected by other factors during the long-term brine evolution process, especially with regard to the water-rock interactions. Considering the geochemical process of

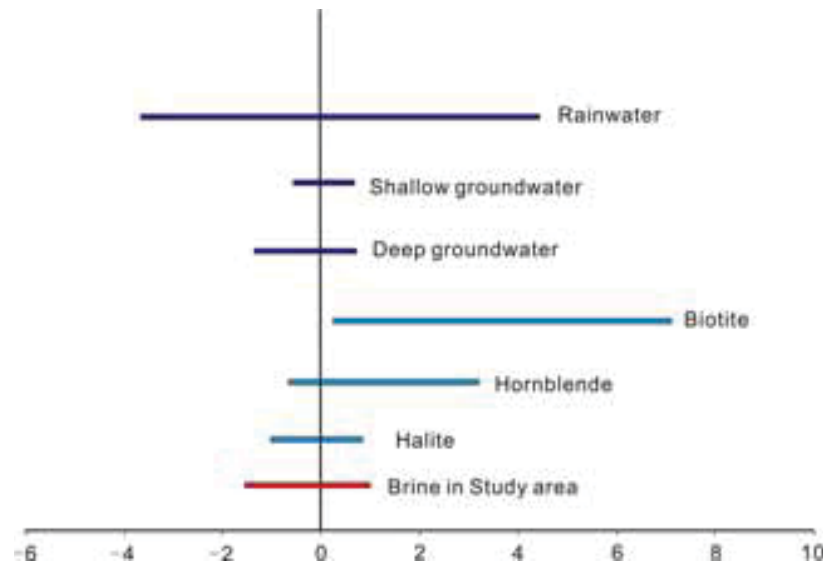

Figure 5. The range of variation of $\delta^{37} \mathrm{Cl}$ in different fluids and saline minerals. Data sources: Rain water (Koehler and Wassenaar 2010); shallow groundwater (Eastoe and Dettman 2016); deep groundwater (Eastoe and Dettman 2016); biotite (Eastoe and Guilbert 1992); hornblende (Eggenkamp and Schuiling 1995); halite (Eggenkamp and Schuiling 1995).

the saline spring formation and the distribution of rocks in the study area, characteristics of the $\mathrm{Cl}$ isotope of rainwater, ground water, biotite and hornblende are shown in figure 5 (Eastoe and Guilbert 1992; Eggenkamp and Schuiling 1995; Koehler and Wassenaar 2010; Eastoe and Dettman 2016). In combination with the hydrogeological conditions of the Nangqen basin, factors that may cause changes in the $\mathrm{Cl} / \mathrm{Br}$ ratio and chlorine isotope characteristic values of brines will also be discussed.

During the dissolution of the halite, the dissolved fluids, whether atmospheric precipitation, groundwater or seawater, the chloride ion content in the dissolved brine is mainly controlled by the solubility of $\mathrm{NaCl}$ in the water, fluid temperature and flow rate. Rainwater is very abundant in the study area, and the chlorine isotope range of the rainwater varies from $-3.5 \%$ o to $+4.48 \%$ (Koehler and Wassenaar 2010). Therefore, rain or groundwater is another factor that can cause changes in chlorine isotopes in the saline springs.

Sandstone, mudstone and volcanic rocks are widely distributed in the exposed strata in the Nangqen basin, while biotite and hornblende may contain several hundred to several thousand ppm of $\mathrm{Cl}$ in igneous and metamorphic rocks, which are the main chlorinecontaining minerals in nature (Kaufmann et al. 1984). The biotite in the Nangqen basin is mainly found in mudstones and volcanic rocks that are widely distributed in this area. Therefore, the leaching of rocks may become another important source of saline springs. Because biotite and amphibole have a high range of $\mathrm{Cl} / \mathrm{Br}$ ratios, they have a great influence on 
the ratio of $\mathrm{Cl} / \mathrm{Br}$ in the saline springs. Based on the published $\delta^{37} \mathrm{C} 1$ compositions of biotite $(-0.26 \%$ $\sim+3.4 \%$ ) and $\delta^{37} \mathrm{Cl}(+0.7 \%$ $+7 \%$ o $)$ in hornblende, the water-rock interactions can cause a shift in the $\delta^{37} \mathrm{Cl}$ values of the brine.

Based on the analysis of $\mathrm{Cl} / \mathrm{Br}$ ratios and $\delta^{37} \mathrm{C} 1$ compositions of saline springs in this area, the following conclusions are drawn: (i) the leaching of halite layers is the main source of salt materials; (ii) abundant chlorine enrichment in atmospheric precipitation will cause an increase in the range of chlorine isotope values; and (iii) the leaching of surrounding rocks (volcanic rocks, mudstones) will cause an increase in the chlorine/bromine ratio and a positive shift in the chlorine isotope value.

\section{Conclusions}

The $[\mathrm{Cl}]$ and $\delta^{37} \mathrm{Cl}$ data from the saline springs of the Nangqen basin are presented here. Our main views are as follows:

(1) The chlorine isotope values range from $-1.55 \%$ to $+0.97 \%$, and the $\mathrm{Cl} / \mathrm{Br}$ ratios of the brine in the Nangqen basin range from 1739 to 175,260 .

(2) Evidence of $\delta^{37} \mathrm{Cl}$ indicates that the saline springs in the study area have been leaching out of the underground halite layers, which is consistent with the results of the $\mathrm{B}$ isotopes and $\mathrm{H}-\mathrm{O}$ isotopes. In addition, during the formation and evolution of the saline springs, the dissolution of mudstones and volcanic rocks are the main causes of chlorine isotopic variation.

(3) On considering the various aspects, it is speculated that the saline springs in the Nangqen basin were leached from the underground salt layer during atmospheric precipitation or groundwater upwelling and then formed on the exposed surface. During the upwelling process, the leaching of bedrock (volcanic rock and carbonate) plays an important role in the supply of boron and chlorine.

\section{Acknowledgements}

The authors are thankful to Dr Ma Yunqi, Associate Research Fellow, for providing valuable suggestions and the help during the laboratory experiments. This research was supported by the science and technology project of the Qinghai province (grant no. 2014-ZJ-702).

\section{References}

Banks D A, Green R, Cliff R A and Yardley B W D 2000 Chlorine isotopes in fluid inclusions: Determination of the origins of salinity in magmatic fluids; Geochim. Cosmochim. Acta 64(10) 1785-1789.

Barnes J D and Sharp Z D 2017 Chlorine isotope geochemistry; Rev. Mineral. Geochem. 82(1) 345-378.

Bodnar R J 1994 Synthetic fluid inclusions: XII. The system $\mathrm{H}_{2} \mathrm{O}-\mathrm{NaCl}$. Experimental determination of the halite liquidus and isochores for a $40 \mathrm{wt} \% \mathrm{NaCl}$ solution; Geochim. Cosmochim. Acta 58(3) 1053-1063.

Bonifacie M, Jendrzejewski N, Agrinier P, Humler E, Coleman $\mathrm{M}$ and Javoy M 2008 The chlorine isotope composition of Earth's mantle; Science 319(5869) 1518-1520.

Brian K, Zhou J, Matt S, An Y and Wang J H 2000 Paleogene (?) deposystems and basin evolution in the Eastern Tibetan Plateau: Nangqian and Xialaxiu basins; Geosci. Front. 7(suppl.) 282-283.

Bureau H, Keppler H and Métrich N 2000 Volcanic degassing of bromine and iodine: Experimental fluid/melt partitioning data and applications to stratospheric chemistry; Earth Planet. Sci. Lett. 183(1-2) 51-60.

Chi G and Savard M M 1997 Sources of basinal and Mississippi Valley-type mineralizing brines: Mixing of evaporated seawater and halite-dissolution brine; Chem. Geol. 143(3) 121-125.

Deng W M, Sun H J and Zhang Y Q 2000 K-Ar age of the Cenozoic volcanic rocks in the Nangqen Basin, Qinghai Province and its geological significance; Chin. Sci. Bull. 45(11) 1015-1019.

Du H F, Jiang Y B, Yan Z B, Hou Z Q, Yang T N, Guo F S and Yang Q K 2011 Sedimentary characteristics and environment of the Paleogene Nangqian Basin in Qinghai Province; Acta Geol. Sin. Engl. 85(3) 383-395 (in Chinese).

Eastoe C J and Dettman D L 2016 Isotope amount effects in hydrologic and climate reconstructions of monsoon climates: Implications of some long-term data sets for precipitation; Chem. Geol. 430 78-89.

Eastoe C J and Guilbert J M 1992 Stable chlorine isotopes in hydrothermal processes; Geochim. Cosmochim. Acta 56(12) 4247-4255.

Eastoe C J, Long A and Knauth L P 1999 Stable chlorine isotopes in the Palo Duro Basin, Texas: Evidence for preservation of Permian evaporite brines; Geochim. Cosmochim. Acta 63(9) 1375-1382.

Eastoe C, Peryt T, Petrychenko Y and Geisler-Cussey D 2007 Stable chlorine isotopes in Phanerozoic evaporites; Appl. Geochem. 22(3) 575-588.

Eggenkamp H G M and Schuiling R D $1995 \Delta^{37} \mathrm{c} 1$ variations in selected minerals: A possible tool for exploration; $J$. Geochem. Explor. 55(1-3) 249-255.

Eggenkamp H G M, Kreulen R and Van Groos A F K 1995 Chlorine stable isotope fractionation in evaporites; Geochim. Cosmochim. Acta 59(24) 5169-5175.

Fontes J C and Matray J M 1993 Geochemistry and origin of formation brines from the Paris Basin, France: 2 Saline solutions associated with oil fields; Chem. Geol. 109(1-4) $149-175$. 
Gleeson S A and Smith M P 2009 The sources and evolution of mineralising fluids in iron oxide-copper-gold systems, Norrbotten, Sweden: Constraints from $\mathrm{Br} / \mathrm{Cl}$ ratios and stable $\mathrm{Cl}$ isotopes of fluid inclusion leachates; Geochim. Cosmochim. Acta 73(19) 5658-5672.

Godon A, Jendrzejewski N, Eggenkamp H G M, Banks D A, Ader M and Coleman M L 2004 A cross-calibration of chlorine isotopic measurements and suitability of seawater as the international reference material; Chem. Geol. 207(1-2) 1-12.

Grandia F 2003 Geochemistry of the fluids related to epigenetic carbonate-hosted $\mathrm{Zn}-\mathrm{Pb}$ deposits in the Maestrat Basin, Eastern Spain: Fluid inclusion and isotope $(\mathrm{Cl}, \mathrm{C}, \mathrm{O}$, S, Sr) evidence; Econ. Geol. 98(5) 933-954.

Han J L, Han F Q, Hussain S A, Liu W Y, Nian X Q and Mao Q F 2018 Origin of boron and brine evolution in saline springs in the Nangqen Basin, Southern Tibetan Plateau; Geofluids 2018 1-12.

Hemming N G and Hanson G N 1992 Boron isotopic composition and concentration in modern marine carbonates; Geochim. Cosmochim. Acta 56(1) 537-543.

Horton B K, Zhou J Y, Spurlin M S and Wang J H 2000 Paleogene deposystems and basin evolution in the eastern Tibetan Plateau: Nangqian and Xialaxiu basins; Earth Sci. Front. 7(suppl.) 282-283.

Jiang Y H, Jiang S Y, Ling H F and Zhang D B 2006 Lowdegree melting of a metasomatized lithospheric mantle for the origin of Cenozoic Yulong monzogranite-porphyry, east Tibet: Geochemical and $\mathrm{Sr}-\mathrm{Nd}-\mathrm{Pb}-\mathrm{Hf}$ isotopic constraints; Earth Planet. Sci. Lett. 241(3) 617-633.

Kaufmann R S, Frape S K, Mcnutt R and Eastoe C 1993 Chlorine stable isotope distribution of Michigan Basin formation waters; Appl. Geochem. 8 403-407.

Kaufmann R, Long A, Bentley H and Davis S 1984 Natural chlorine isotope variations; Nature 309 338-340.

Koehler G and Wassenaar L I 2010 The stable isotopic composition $\left({ }^{37} \mathrm{Cl} /{ }^{35} \mathrm{Cl}\right)$ of dissolved chloride in rainwater; Appl. Geochem. 25(1) 91-96.

Liu W G and Xiao Y K 1996 Chlorine isotopic composition in Qaidam Basin; Geochimica 25(3) 296-303.

Liu W G, Xiao Y K, Wang Q Z, Qi H P, Wang Y H, Zhou Y M and Shirodkar P V 1997 Chlorine isotopic geochemistry of salt lakes in the Qaidam Basin, China; Chem. Geol. 136(3) 271-279.

Liu W G, Peng Z C and Xiao Y K 1998 Boron and chlorine isotopic determinations and applications for earth sciences; Adv. Earth Sci. 13(6) 38-45.

Luo C G, Xiao Y K, Ma H Z, Ma Y Q, Zhang Y L and He M Y 2012 Stable isotope fractionation of chlorine during evaporation of brine from a saline lake; Chin. Sci. Bull. 57(15) 1833-1843.

Luo C G, Xiao Y K, Wen H J, Ma H Z, Ma Y Q, Zhang Y L and He M Y 2015 Reply to the comment on the paper 'Stable isotope fractionation of chlorine during the precipitation of single chloride minerals'; Appl. Geochem. 54 117-118.

Lv Y Y, Zheng M P, Zhao P and Xu R H 2014 Geochemical processes and origin of boron isotopes in geothermal water in the Yunnan-Tibet geothermal zone; Earth Sci. 57(12) 2934-2944.

Magenheim A J, Spivack A J, Volpe C and Ransom B 1994 Precise determination of stable chlorine isotopic ratios in low-concentration natural samples; Geochim. Cosmochim. Acta 58(14) 3117-3121.

Nahnybida T, Gleeson S A, Rusk B G and Wassenaar L I 2009 $\mathrm{Cl} / \mathrm{Br}$ ratios and stable chlorine isotope analysis of magmatic-hydrothermal fluid inclusions from Butte, Montana and Bingham Canyon, Utah; Miner. Deposita 44(8) 837-848.

Qi Z, Li Y, Wang C, Sun T and Zhang J 2017 Organic geochemistry of the Paleocene-Eocene oil shales of the Gongjue formation, Nangqian basin, east-central Tibetan plateau; Oil Shale 34(1) 1-14.

Richard A, Banks D A, Mercadier J, Boiron M C, Cuney M and Cathelineau M 2011 An evaporated seawater origin for the ore-forming brines in unconformity-related uranium deposits (Athabasca Basin, Canada): $\mathrm{Cl} / \mathrm{Br}$ and $\delta^{37} \mathrm{Cl}$ analysis of fluid inclusions; Geochim. Cosmochim. Acta 75(10) 2792-2810.

Risacher F, Alonso H and Salazar C 2003 The origin of brines and salts in Chilean salars: A hydrochemical review; EarthSci. Rev. 63 249-293.

Rodríguez A, Bergen J and Eggenkamp H G M 1997 Isotopic compositions of chlorine in brine and saline minerals; Chin. Sci. Bull. 42(5) 406-409.

Sharp Z D, Barnes J D, Brearley A J, Chaussidon M, Fischer T P and Kamenetsky V S 2007 Chlorine isotope homogeneity of the mantle, crust and carbonaceous chondrites; Nature 446(7139) 1062-1065.

Spurlin M S, Yin A, Horton B K, Zhou J Y and Wang J H 2015 Structural evolution of the Yushu-Nangqian region and its relationship to syncollisional igneous activity, east-central Tibet; Geol. Soc. Am. Bull. 117(9-10) 1293-1317.

Tan H B, Ma H Z, Xiao Y K, Wei H Z and Zhang X Y 2005 Characteristics of chlorine isotope distribution and analysis on sylvinite deposit formation based on ancient salt rock in the western Tarim Basin; Sci. China: Earth Sci. 48(11) 1913-1920.

Vengosh A, Chivas A R and Mcculloch M T 1989 Direct determination of boron and chlorine isotopic compositions in geological materials by negative thermal-ionization mass spectrometry; Chem. Geol. Isot. Geosci. 79(4) 333-343.

Xiao Y K, Liu W G and Zhang C G 1994 The preliminary investigation on chlorine isotopic fractionation during the crystallization of saline minerals in salt lake; J. Salt Lake Res. 2(3) 27-34 (in Chinese).

Xiao Y K, Liu W G, Qi H P and Wang Y H 1998 The new methods for isotopic measurement of elements by mass spectrometry and investigation of its application; J. Salt Lake Res. 6(2-3) 73-85 (in Chinese).

Xiao Y K, Wei H Z and Yin D Z 2000 Progress on isotopic geochemistry of boron and chlorine in salt lakes; J. Salt Lake Res. 8(1) 30-40 (in Chinese).

Xu J X, Ma H Z, Xiao Y K, Tan H B, Li T W, Sun Z G and Fan Q S 2008 Stable chlorine isotope and Its research on applied geochemistry; J. Salt Lake Res. 16(1) 51-59 (in Chinese).

Yang D X 1988 The determinations of plateau age by ${ }^{40} \mathrm{Ar} /{ }^{39} \mathrm{Ar}$ dating on Cenozoic calc-alkalic trachytes of Nangqen Basin, Northern transverse mountains; In: Contribution to the Geology of the Qinghai-Xizang (Tibet) Plateau, Geological Publishing House, Beijing 19 9-44 (in Chinese). 